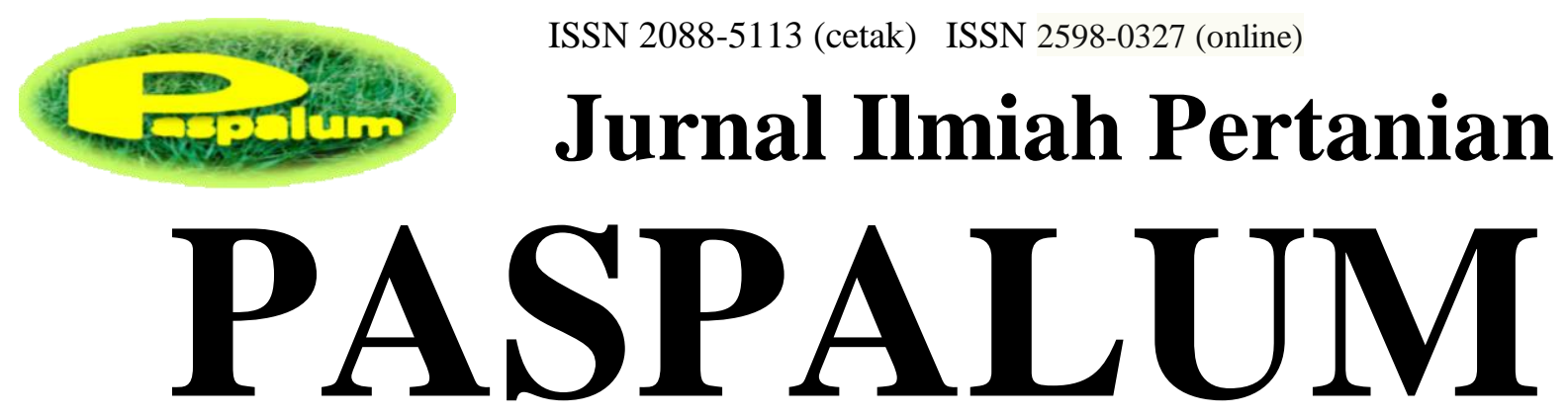

Vol. 7 No. 1 Bulan Maret Tahun 2019

http://journal.unwim.ac.id/index.php/paspalum

\title{
Optimasi Pupuk NPK Majemuk, Pupuk Daun Dan POC Urin Sapi Pada Hidroponik Sistem Wick Terhadap Produksi Tanaman Kubis Bunga (Brasicca oleracea L. Var. Botrytis Sub.Var. Cauliflora DC) Kultivar PM 126 F1.
}

\author{
Laksono, R.A, dan Sugiono, D. \\ Fakultas Pertanian Universitas Singaperbangsa Karawang \\ rommy.laksono@faperta.unsika.ac.id
}

Diterima tgl 20 Desember 2018 dan disetujui untuk diterbitkan tgl 15 Februari 2019

\begin{abstract}
There are several factors that cause a decrease in the production of Cabbage Flowers in Indonesia, including inadequate cultivation systems, less optimal nutrition, and a lack of utilization of organic elements in cultivation techniques, as well as the use of urban narrow land. The purpose of this study was to study and obtain a combination of compound NPK fertilizer, leaffertilizer and POC cow urine which gave the highest production of PM 126 F1 variety flower cabbage plants on the wick hydroponic system. This research was conducted at Screen House, located in West Jomin Village, Kota Baru Subdistrict, Karawang Regency, West Java Province. The research site is at an altitude of 10 meters above sea level, from April to September 2018. The method used is the experimental method and the experimental design used was Randomized Block Design (RBD) consisting of 10 treatments repeated 3 times. Data were analyzed using variance analysis and further testing with Duncans multiple range test at the level of 5\%. The results of this study are compound NPK fertilizer optimization, leaf fertilizer and POC cow urine on the wick hydroponic system that have a significant effect on growth components (plant height 42 days, number of leaves 42 days, stem diameter 42 days, root display, and leaf area), and gave a significantly different effect on the yield component (flower height, flower diameter, leaf weight without leaves, and flower weight with leaves) flower cabbage plant cultivar PM126F1. Treatment A (AB Mix $10 \mathrm{ml} \mathrm{L} L^{-1}$ water) gave the highest yield on flower weight (crop) with leaves per plant of 536.056 gr equivalent to 22.34 tons per hectare and weight of flowers (crop) without leaves per plant of 207.57 gr equivalent to 8.65 tons per hectare.
\end{abstract}

Keywords: Flower Cabbage, Nutrition, PM126 F1

\begin{abstract}
Abstrak
Ada beberapa faktor yang menyebabkan penurunan produksi Kubis Bunga di Indonesia, diantaranya sistem budidaya yang kurang tepat, nutrisi yang kurang optimal, dan kurangnya pemanfaatan unsur organik dalam teknik budidayanya, serta pemanfaatan lahan sempit perkotaan. Tujuan penelitian ini adalah untuk mempelajari dan mendapatkan kombinasi pupuk NPK majemuk, pupuk daun dan POC urin sapi yang memberikan produksi tanaman kubis bunga varietas PM 126 F1
\end{abstract}


tertinggi pada hidroponik sistem wick. Penelitian ini dilaksanakan di Screen House bertempat di Desa Jomin Barat, Kecamatan Kota Baru, Kabupaten Karawang, Provinsi Jawa Barat. Tempat penelitian berada pada ketinggian $10 \mathrm{mdpl}$, pada bulan April sampai dengan bulan September 2018. Metode yang digunakan adalah metode eksperimen dan rancangan percobaan yang digunakan adalah Rancangan Acak Kelompok (RAK) terdiri atas 10 perlakuan diulang 3 kali. Data dianalisis menggunakan analisis ragam dan uji lanjut dengan uji jarak berganda Duncans pada taraf 5\%. Hasil yang dicapai dari kajian ini adalah optimasi pupuk NPK majemuk, pupuk daun dan POC urin sapi pada hidroponik sistem wick memberikan pengaruh terhadap komponen pertumbuhan (tinggi tanaman 42 hst, jumlah daun 42 hst, diameter batang 42 hst, pajang akar, dan luas daun), serta memberikan pengaruh terhadap komponen hasil (tinggi bunga, diameter bunga, bobot bunga tanpa daun, dan bobot bunga dengan daun) tanaman kubis bunga kultivar PM126F1. Perlakuan A (AB Mix $10 \mathrm{ml} \mathrm{L}^{-1}$ air) memberikan hasil tertinggi pada bobot bunga (krop) dengan daun per tanaman sebesar 536,056 gr setara dengan 22,34 ton per hektar dan bobot bunga (krop) tanpa daun per tanaman sebesar 207,57 gr setara dengan 8,65 ton per hektar.

Kata kunci : Kubis Bunga, Nutrisi, PM126 F1

\section{PENDAHULUAN}

Kubis bunga atau banyak dikenal masyarakat dengan nama kembang kol atau blumkol merupakan tanaman sayuran yang masuk kedalam famili Brassicaceae berupa tumbuhan berbatang lunak. Tanaman ini dikenal sebagai tanaman subtropik, dengan perkembangan teknologi pertanian telah ditemukan varietas-varietas kubis bunga yang cocok ditanam di daerah dataran rendah. Prospek pasar tanaman kubis bunga di Indonesia cukup baik karena kandungan gizi dan vitamin yang dikandung baik untuk kesehatan tubuh manusia.

Salah satu permasalahan produksi kubis bunga di era modernisasi adalah peningkatan alih fungsi lahan sehingga semakin sempitnya lahan pertanian, khususnya di daerah perkotaan yang memiliki pemukiman padat karena pertambahan penduduk yang cepat akibat faktor kelahiran, perpindahan penduduk, dan urbanisasi. Faktor pertambahan penduduk yang pesat disertai dengan kemajuan teknologi dan industri pada akhirnya akan menggeser fungsi lahan pertanian menjadi lahan perumahan dan industri.

Salah satu cara mengatasi permasalahan tersebut dengan cara penerapan teknologi pertanian non konvensional, yang diharapkan mampu meningkatkan produksi sayuran pada daerah perkotaan dengan memanfaatkan lahan sempit. Salah satu model pertanian non konvensional yang representatif untuk diterapkan yaitu hidroponik. Hidroponik adalah teknik budidaya tanaman yang menggunakan media tumbuh selain tanah, dengan kata lain dapat juga diartikan sebagai budidaya tanpa tanah. System hidoponik memiliki keuntungan keberhasilan penanaman terjamin, perawatan mudah, pupuk efisien, produksi continue, haraga tinggi, bisa melakukan di luar musim, dapat dilakukan ditempat sempit dan tidak terkena banjir atau erosi (Roidah, 2014).

Teknik hidroponik sistem sumbu (wick) merupakan teknik budidaya yang sederhana dibandingkan dengan sistem hidroponik lainnya. Sistem wick tidak harus memiliki peralatan yang rumit, hanya menggunakan sumbu sebagai media perantara antara nutrisi dengan zona perakaran. Hidroponik sistem wick, jika reservoir nutrisi habis, dapat diisi kembali secara manual (Halim, 2016). Kelebihan hidroponik sumbu adalah biaya pembuatan murah, mudah perawatan, tanaman tidak perlu dilakukan penyiraman secara terus menerus. Hidroponik sumbu biasanya digunakan di dalam ruangan dengan media tanam yang ringan. 
Peluang peningkatan produksi dan produktivitas kubis bunga masih sangat terbuka lebar salah satunya dengan peningkatan teknologi pemupukan, dengan memanfaatkan unsur anorganik dan unsur organik.

Pada budidaya tanaman dengan sistem hidroponik, nutrisi yang biasa digunakan petani hidroponik adalah $\mathrm{AB}$ Mix, yaitu pupuk khusus yang dirancang untuk memenuhi unsur hara pada tanaman dengan sistem hidroponik. Namun, harga jual AB Mix ini masih tinggi. Banyak upaya yang dilakukan untuk membuat nutrisi alternatif pada pemupukan dengan sistem hidroponik. Pemanfaatan pupuk organik bersama pupuk anorganik dalam sistem pengelolaan hara terpadu spesifik lokasi seperti tertuang dalam Permentan No. 40/2007 tentang Rekomendasi Pupuk N, P, K (Hartatik et al., 2015). Pupuk daun dapat dijadikan salah satu alternatif sumber nutrisi, Pupuk daun dapat dengan mudah ditemukan di pasaran. Penggunaan pupuk daun ini dapat dikombinasi dengan pupuk anorganik salah satunya adalah pupuk NPK majemuk.

Urin sapi merupakan salah satu alternatif untuk meningkatkan ketersediaan, kecukupan, dan efisiensi serapan hara bagi tanaman yang mengandung mikroorganisme sehingga dapat mengurangi penggunaan pupuk anorganik dan meningkatkan hasil tanaman secara maksimal. Pemberian pupuk organik cair merupakan salah satu cara untuk mendapatkan tanaman bayam organik yang sehat dengan kandungan hara yang cukup tanpa penambahan pupuk (Dharmayanti et al., 2013). POC urin sapi dapat digunakan sebagai nutrisi alternatif untuk pemupukan tanaman secara organik. Penggunaan POC urin sapi ini sebagai salah satu sumber nutrisi alternatif pada budidaya tanaman secara hidroponik. Urin sapi memiliki kandungan unsur hara makro dan mikro bagi kelangsungan hidup tanaman. Namun ketersediaannya hanya beberapa persen dari kandungan pupuk anorganik (Kusumah et al., 2016).

\section{METODE}

Penelitian ini dilaksanakan di Screen House bertempat di Desa Jomin Barat, Kecamatan Kota Baru, Kabupaten Karawang, Provinsi Jawa Barat. Tempat penelitian berada pada ketinggian $10 \mathrm{mdpl}$, pada bulan Juli sampai dengan bulan September 2018. Bahan yang digunakan adalah benih kubis bunga kultivar PM 126 F1, nutrisi makro dan mikro tanaman hidroponik (AB MIX), urin sapi, starter EM 4, gula merah (molase), pupuk NPK, Gandasil B, air. Pemberian pupuk daun Gandasil B diberikan setiap 10 hari sekali pada umur 30 hst, 40 hst dan 50 hst sesuai dengan dosis perlakuan dengan cara dilarutkan pada tandon air. Pemberian pupuk NPK majemuk dilakukan pada saat pindah tanam dengan cara di tabur pada jarak $5 \mathrm{~cm}$ dari tanaman dan pemupukan susulan dilakukan pada umur 15 hst, dan 30 hst sesuai dengan dosis perlakuan. Pemupukan pupuk organik cair dilakukan pada waktu pagi hari antara pukul 07.00-10.00 WIB dengan cara dilarutkan pada tandon air. Pemberian $\mathrm{AB}$ mix dilakukan pada saat awal tanam sesuai dengan dosis perlakuan dengan cara melarutkan pekatan pada tandon air.

Penelitian mengunakan Rancangan Acak Kelompok (RAK), terdiri atas 10 perlakuan diulang 3 kali : A. AB Mix $10 \mathrm{ml} \mathrm{L}^{-1}$ air; B.Urine sapi $100 \mathrm{ml} \mathrm{L}^{-1}$ air; C.Gandasil $4 \mathrm{gr} \mathrm{L}^{-}$ ${ }^{1}$ air; D.NPK 21,6 gr pertanaman; E.NPK 21,6 gr pertanaman + Gandasil 2 gr/lt air; F.NPK 21,6 gr pertanaman +Gandasil 4 gr $\mathrm{L}^{-1}$ air; G.NPK 21,6 gr peranaman + Gandasil 6 gr L ${ }^{-1}$ air; H.NPK 21,6 gr pertanaman + Urine Sapi $80 \mathrm{ml} \mathrm{L}^{-1}$ air; I.NPK 21,6 gr pertanaman + Urine Sapi $100 \mathrm{ml} \mathrm{L}^{-1}$ air; J.NPK 21,6 gr peretanaman + Urine Sapi $120 \mathrm{ml} \mathrm{L}^{-1}$ air. Data dianalisis menggunakan analisis ragam dan uji lanjut dengan uji jarak berganda Duncans pada taraf $5 \%$. 
HASIL DAN PEMBAHASAN

\section{Pengamatan Penunjang}

Hasil analisis kandungan pupuk organik cair urin sapi menurut Ranchman (2002), menunjukan bahwa POC urine sapi mengandung $(1,1 \% \mathrm{~N}, 0,5 \% \mathrm{P}, 0,9 \% \mathrm{~K}, 1,1 \%$ $\mathrm{Ca}, 1 \% \mathrm{Hg}, 0,2 \% \mathrm{Na}, 34 \% \mathrm{Mn}, 22 \% \mathrm{Zn}$, $20 \% \mathrm{Cu}$, dan $6 \% \mathrm{Cr}$ ). Berdasarkan ketentuan kriteria penilaian sifat kimia pupuk organik berdasarkan Permentan No.70 Tahun 2011 tentang Pupuk Organik, Pupuk Hayati, dan Pembenah Tanah, maka kandungan bokashi yang digunakan dalam percobaan ini memenuhi persyaratan tersebut. Suhu harian selama percobaan berlangsung berkisar antara $28^{\circ} \mathrm{C}-39^{\circ} \mathrm{C}$ dengan rata-rata suhu $34,35^{\circ} \mathrm{C}$, sedangkan kelembababn relatif udara berkisar antara $45 \%$ - $75 \%$ dengan rata-rata kelembaban $61,30 \%$. Menurut data UPTD PJT II Kecamatan Kota Baru (2018) semala percobaan (Juli-September 2018) jumlah curah hujan harian sebesar $764 \mathrm{~mm}$, dengan rata-rata hujan per hari $11,75 \mathrm{~mm}$. Menurut Pracaya (2011) Kubis bunga dataran rendah memerlukan suhu $28{ }^{0} \mathrm{C}-32{ }^{0} \mathrm{C}$ selama siklus hidupnya. Apabila tidak terpenuhi maka akan terganggu pertumbuhan vegetatif dan waktu pembungaannya. $\mathrm{pH}$ larutan nutrisi semala percobaan berkisar 5,5-7,0 dengan rata-rata $\mathrm{pH}$ larutan 6,5, hal ini memungkinkan untuk penyerapan unsur hara makro dan mikro esensial secara optimal, sehingga pertumbuhan dan hasil tanaman kubis bunga bisa maksimal. Selama percobaan dilaksanakan tidak ditemukan adanya serangan penyakit. Fungisida sistemik yang berbahan aktif Trifloksistrobin 25\% dan Tebukonazol $50 \%$ juga diberikan dengan dosis $0,4 \mathrm{~g} \mathrm{~L}^{-1}$ air, untuk mencegah serangan penyakit tanaman. Penyemprotan dilakukan pada sore hari menjelang malam. Hama yang menyerang selama percobaan berlangsung adalah Belalang Hijau (Atractomorpha crenulata) dan Ulat Grayak (Spodoptera litura L). Pengendalian dilakukan secara kimiawi menggunakan hand sprayer dengan insektisida kontak yang berbahan aktif Deltamethrin $25 \mathrm{~g}$ $\mathrm{L}^{-1}$ dengan dosis $0,5 \mathrm{ml} \mathrm{L}^{-1}$ air.

\section{Pengamatan Utama}

\section{Tinggi Tanaman, Jumlah Daun, dan Diameter Batang.}

Data hasil analisis menunjukan bahwa kombinasi pupuk NPK majemuk, pupuk daun dan POC urin sapi pada hidroponik sistem wick memberikan pengaruh yang berbeda nyata terhadap tinggi tanaman, jumlah daun, dan diameter batang tanaman kubis bunga kultivar PM126F1 umur 42 Hst (Tabel 1). Pada rata-rata tinggi tanaman dan jumlah daun kubis bunga kultivar PM126F1 umur 42 hst, kombinasi pupuk NPK majemuk, pupuk daun dan POC urin sapi pada hidroponik sistem wick memberikan pengaruh yang berbeda nyata (Tabel 1).

Hasil tertinggi tinggi tanaman dan jumlah daun diperolehan perlakuan H (NPK 21,6 gr/ tanaman + Urine Sapi $80 \mathrm{ml} \mathrm{L}^{-1}$ air) dengan tinggi tanaman sebesar $36,81 \mathrm{~cm}$, berbeda nyata dengan perlakuan $\mathrm{C}$, akan tetapi berbeda tidak nyata dengan perlakuan lainya, sedangkan jumlah daun tertinggi sebesar sebesar 23,44 helai berbeda nyata dengan perlakuan C, D,E, dan G, akan tetapi berbeda tidak nyata dengan perlakuan lainya. Hal ini diduga pemberian NPK yang dikombinasikan dengan POC urine sapi dengan takaran optimal mampu mempercepat pertumbuhan tanaman di fase vegetatif, sifat NPK majemuk yang merupakan pupuk anorganik yang bersifat fast release memungkinkan tanaman mendapatkan unsur makro esensisal lebih maksimal saat fase vegetatif, sedangkan pemberian POC urien dengan dosis $80 \mathrm{ml} / \mathrm{lt}$ air, mampu mencukupi kebutuhan unsur mikro esensial secara optimal. Unsur mikro esensisal dibutuhkan tanaman dalam jumlah sedikit, jika berlebih akan bersifat racun yang menyebabkan tanaman mati, selain itu urien sapi yang terfermantasi banyak mengandung hormon auksin yang memberikan respon bagi perkembangan sel-sel untuk kepentingan pertumbuhan, sehingga hasil menunjukkan bahwa tinggi tanaman dan jumlah daun yang 
diperoleh dari POC urine sapi dengan dosis optimal memberikan respon tertinggi. Gardner et al. (1991) menyatakan bahwa pertumbuhan tinggi batang terjadi di dalam meristem interkalar dari ruas. Ruas itu memanjang sebagai akibat meningkatnya jumlah sel dan terutama karena adanya pemanjangan sel yang dapat menyebabkan peningkatan sampai 25 $\mathrm{cm}$ atau lebih. Pertumbuhan karena pembelahan sel terjadi pada dasar ruas (interkalar). Lingga P dan Marsono (2007), menyatakan fermentasi urine sapi secara ilmiah mengandung zat pengatur tumbuh yaitu auksin golongan IAA.

Pada rata-rata diameter batang tanaman kubis bunga kultivar PM126F1 umur umur 42 hst, kombinasi pupuk NPK majemuk, pupuk daun dan POC urin sapi pada hidroponik sistem wick memberikan pengaruh yang berbeda nyata (Tabel 1). Hasil tertinggi diperolehan perlakuan A (AB Mix $10 \mathrm{ml} \mathrm{L}^{-1}$ air) sebesar $1,33 \mathrm{~cm}$, berbeda nyata dengan perlakuan $\mathrm{C}$ dan $\mathrm{E}$, akan tetapi berbeda tidak nyata dengan perlakuan lainya. Hal ini diduga AB Mix merupakan pupuk khusus hidroponik yang terbentuk dari garam-garam mineral yang mampu menyuplai unsur makro dan mikro esensisal, sehingga kebutuhan tanaman dalam pembesaran batang dapat terpenuhi secara maksimal. Penggunaan sistem hidroponik wick sistem mampu menjaga kebutuhan air sehingga unsur hara dapat diserap akar dengan cepat didalam tandon nurisi dengan perantara sumbu yang tersedia. Menurut Munawar (2011), jika jaringan tumbuhan mengandung unsur hara tertentu dengan konsentrasi yang lebih tinggi dari konsentrasi yang dibutuhkan maka pertumbuhan maksimum. Selain itu nutrisi $\mathrm{AB}$ mix lebih mudah larut dalam media air sehingga ketersediaan unsur hara terlarut lebih banyak.

Tabel 1. Pengaruh Pupuk NPK Majemuk, Pupuk Daun dan POC Urin Sapi pada Hidroponik Sistem Wick terhadap Rata-rata Tinggi Tanaman, Jumlah Daun, dan Diameter Batang Kubis Bunga Kultivar PM 126 F1.

\begin{tabular}{|c|c|c|c|c|c|c|}
\hline \multirow[b]{2}{*}{$\begin{array}{l}0 \\
0 \\
0\end{array}$} & \multirow[b]{2}{*}{ Perlakuan } & \multicolumn{5}{|c|}{$\begin{array}{c}\text { Komponen Pertumbuhan Vegetatif } 42 \\
\text { Hst }\end{array}$} \\
\hline & & \multicolumn{2}{|c|}{$\begin{array}{c}\text { Tinggi } \\
\text { Tanaman } \\
(\mathrm{cm})\end{array}$} & \multicolumn{2}{|c|}{$\begin{array}{c}\text { Jumlah } \\
\text { Daun } \\
\text { (helai) }\end{array}$} & $\begin{array}{c}\text { Diameter } \\
\text { Batang } \\
(\mathrm{cm})\end{array}$ \\
\hline A & $\mathrm{AB}$ Mix $10 \mathrm{ml} \mathrm{L}^{-1}$ air & 36,78 & $\mathrm{a}$ & 23,28 & $\mathrm{ab}$ & $1,33 \mathrm{a}$ \\
\hline B & Urine sapi $100 \mathrm{ml} \mathrm{L}^{-1}$ air & 33,86 & $\mathrm{a}$ & 21,83 & $a b c$ & 1,23 \\
\hline $\mathrm{C}$ & Gandasil $4 \mathrm{gr} \mathrm{L}^{-1}$ air & 27,44 & $\mathrm{~b}$ & 18,61 & $\mathrm{~d}$ & 0,94 \\
\hline $\mathrm{D}$ & NPK 21,6 gr/tanaman & 32,46 & $\mathrm{a}$ & 20,89 & c & 1,22 \\
\hline $\mathrm{E}$ & NPK 21,6 gr/ tanaman + Gandasil $2 \mathrm{gr} \mathrm{L}^{-1}$ air & 32,80 & $\mathrm{a}$ & 21,00 & $\mathrm{c}$ & 1,19 \\
\hline $\mathrm{F}$ & NPK 21,6 gr/ tanaman +Gandasil $4 \mathrm{gr} \mathrm{L}^{-1}$ air & 33,74 & a & 22,39 & $a b c$ & 1,26 \\
\hline G & NPK 21,6 gr/ tanaman + Gandasil $6 \mathrm{gr} \mathrm{L}^{-1}$ air & 33,93 & $\mathrm{a}$ & 21,33 & $\mathrm{bc}$ & 1,26 \\
\hline $\mathrm{H}$ & NPK 21,6 gr/ tanaman + Urine Sapi $80 \mathrm{ml} \mathrm{L}^{-1}$ air & 36,81 & a & 23,44 & $\mathrm{a}$ & 1,28 \\
\hline I & NPK 21,6 gr/ tanaman + Urine Sapi $100 \mathrm{ml} \mathrm{L}^{-1}$ air & 33,10 & $\mathrm{a}$ & 23,28 & $a b$ & 1,23 \\
\hline $\mathrm{J}$ & NPK 21,6 gr/ tanaman + Urine Sapi $120 \mathrm{ml} \mathrm{L}^{-1}$ air & 36,59 & $\mathrm{a}$ & 23,22 & & 1,27 \\
\hline & KK (Koefisien Keragaman) \% & \multicolumn{2}{|c|}{6,57} & \multicolumn{2}{|c|}{4,84} & 5,08 \\
\hline
\end{tabular}

Keterangan: Nilai rata-rata pada kolom yang sama yang diikuti huruf yang sama menunjukan tidak berbeda nyata pada uji lanjut DMRT taraf 5\% 


\section{Panjang Akar, dan Luas Daun}

Data hasil analisis menunjukan bahwa kombinasi pupuk NPK majemuk, pupuk daun dan POC urin sapi pada hidroponik sistem wick memberikan pengaruh yang berbeda nyata terhadap panjang akar, dan luas daun tanaman kubis bunga kultivar PM126F1.

Pada rata-rata pajang akar tanaman kubis bunga kultivar PM126F1, kombinasi pupuk NPK majemuk, pupuk daun dan POC urin sapi pada hidroponik sistem wick memberikan pengaruh yang berbeda nyata (Tabel 2). Hasil tertinggi diperolehan perlakuan I (NPK 21,6 gr/ tanaman + Urine Sapi $100 \mathrm{ml} \mathrm{L}^{-1}$ air) sebesar $37,91 \mathrm{~cm}$ berbeda nyata dengan perlakuan B dan E, akan tetapi berbeda tidak nyata dengan perlakuan lainya.

Hal ini diduga kombinasi NPK dan POC Urine sapi mampu meningkatkan pertumbuhan sel akar, karena kandungan unsur makro dan mikro esensial seperti $\mathrm{N}, \mathrm{P}, \mathrm{K}, \mathrm{Zn}$, dan $\mathrm{Ca}$ yang tinggi mampu membentuk akar tanaman lebih cepat sehingga mampu menyerap hara lebih optimal. Poerwowidodo (1992) bahwa protein merupakan penyusun utama protoplasma yang berfungsi sebagai pusat proses metabolisme dalam tanaman yang selanjutnya akan memacu pembelahan dan pemanjangan sel.

Pada rata-rata luas daun tanaman kubis bunga kultivar PM126F1, kombinasi pupuk NPK majemuk, pupuk daun dan POC urin sapi pada hidroponik sistem wick memberikan pengaruh yang berbeda nyata (Tabel 2). Hasil tertinggi diperolehan perlakuan A (AB Mix $10 \mathrm{ml} \mathrm{L}^{-1}$ air) sebesar $4780,97 \mathrm{~cm}^{2}$ berbeda nyata dengan perlakuan lainya. Hal ini diduga $\mathrm{AB}$ mix memiliki kandungan unsur $\mathrm{N}$ lebih tinggi dan stabil pada setiap fase vegetatif dibandungkan perlakuan lainya, sehingga pembentukan protein dan fitohormon sitokinin yang tersusun dari unsur $\mathrm{N}$ sebagai pemebentukan sel daun dan lebih maksimal, selain itu, $\mathrm{N}$ merupakan penyusun klorofil sehingga meningkatkan aktivitas fotosintesis yang akan menghasilkan fotosintat yang mengakibatkan perkembangan pada jaringan meristematis daun. Nutrisi dan mineral yang ada dan tersedia bagi tanaman, terutama nitrogen memiliki pengaruh yang paling menonjol terhadap pertumbuhan dan perkembangan tanaman (Erawan et al., 2013).

Tabel 2. Pengaruh Pupuk NPK Majemuk, Pupuk Daun dan POC Urin Sapi pada Hidroponik Sistem Wick terhadap Rata-rata Panjang Akar dan Luas Daun Kubis Bunga kultivar PM 126 F1.

\begin{tabular}{|c|c|c|c|c|}
\hline \multirow[b]{2}{*}{$\begin{array}{l}\frac{0}{8} \\
1\end{array}$} & \multirow[b]{2}{*}{ Perlakuan } & \multicolumn{3}{|c|}{ Komponen Pertumbuhan per Tanaman } \\
\hline & & $\begin{array}{c}\text { Panjang } \\
\text { Akar }(\mathrm{cm})\end{array}$ & \multicolumn{2}{|c|}{$\begin{array}{c}\text { Luas } \\
\text { Daun }\left(\mathrm{cm}^{2}\right)\end{array}$} \\
\hline A & AB Mix $10 \mathrm{ml} \mathrm{L}^{-1}$ air & $33,47 \quad \mathrm{a}$ & 4780,97 & $\mathrm{a}$ \\
\hline B & Urine sapi $100 \mathrm{ml} \mathrm{L}^{-1}$ air & $26,09 \quad b$ & 2916,13 & $\mathrm{bc}$ \\
\hline $\mathrm{C}$ & Gandasil $4 \mathrm{gr} \mathrm{L}^{-1}$ air & 34,99 a & 1748,00 & $\mathrm{~d}$ \\
\hline $\mathrm{D}$ & NPK 21,6 gr/tanaman & 34,98 & 2359,36 & $\mathrm{~cd}$ \\
\hline $\mathrm{E}$ & NPK 21,6 gr/ tanaman + Gandasil $2 \mathrm{gr} \mathrm{L}^{-1}$ air & 27,36 & 3393,22 & $\mathrm{~b}$ \\
\hline $\mathrm{F}$ & NPK 21,6 gr/ tanaman +Gandasil $4 \mathrm{gr} \mathrm{L}^{-1}$ air & 33,75 & 2157,90 & $\mathrm{~cd}$ \\
\hline G & NPK 21,6 gr/ tanaman + Gandasil $6 \mathrm{gr} \mathrm{L}^{-1}$ air & 36,21 & 3468,48 & $\mathrm{~b}$ \\
\hline $\mathrm{H}$ & NPK 21,6 gr/ tanaman + Urine Sapi $80 \mathrm{ml} \mathrm{L}^{-1}$ air & 36,08 & 3488,30 & $b$ \\
\hline I & NPK 21,6 gr/ tanaman + Urine Sapi $100 \mathrm{ml} \mathrm{L}^{-1}$ air & $37,91 \quad$ a & 3624,27 & $\mathrm{~b}$ \\
\hline $\mathrm{J}$ & NPK 21,6 gr/ tanaman + Urine Sapi $120 \mathrm{ml} \mathrm{L}^{-1}$ air & 34,78 a & 3300,89 & $\mathrm{~b}$ \\
\hline & KK (Koefisien Keragaman) \% & 9,65 & 13,5 & \\
\hline
\end{tabular}

Keterangan: Nilai rata-rata pada kolom yang sama yang diikuti huruf yang sama menunjukan tidak berbeda nyata pada uji lanjut DMRT taraf 5\% 


\section{Tinggi Bunga, Diameter Bunga, Bobot Bunga Tanpa Daun, dan Bobot Bunga Dengan Daun}

Data hasil analisis menunjukan bahwa kombinasi pupuk NPK majemuk, pupuk daun dan POC urin sapi pada hidroponik sistem wick memberikan pengaruh yang berbeda nyata terhadap tinggi bunga, diameter bunga, bobot bunga tanpa daun, dan bobot bunga dengan daun tanaman kubis bunga kultivar PM126F1.

Pada rata-rata tinggi bunga, diameter bunga, bobot bunga tanpa daun, dan bobot bunga dengan daun tanaman kubis bunga kultivar PM126F1, kombinasi pupuk NPK majemuk, pupuk daun dan POC urin sapi pada hidroponik sistem wick memberikan pengaruh yang berbeda nyata (Tabel 3). Hasil tertinggi secara konsisten diperolehan perlakuan A ( $\mathrm{AB}$ Mix $10 \mathrm{ml} \mathrm{L}^{-1}$ air) dengan tinggi bunga sebesar $8,18 \mathrm{~cm}$, diameter bunga sebesar 12,70 $\mathrm{cm}$, bobot bunga tanpa daun sebesar 207,57 gr, dan bobot bunga dengan daun sebesar 536,056 gr berbeda nyata dengan perlakuan lainya. Hal ini diduga $\mathrm{AB}$ Mix mampu menyediakan unsur makro dan mikro esensisal yang maksimal dari fase vegetatif dan semakin meningkat saat fase generatif, hal ini terlihat pada komponen hasil dan hasil percobaan ini (Tabel 3). Aplikasi AB mix yang dilakukan pada sistem wick hidroponik mampu meningkatkan fungsi nutrisi yang larut dalam air sehingga mampu meningkatkan pembentukan protoplasma, terutama untuk pembentukan meristemmatik saat fase vegetatif dan mampu menstabilkan tugor sel tanaman serta meningkatkan transfer garamgaram mineral saat fase generatif sehingga mampu mempercepat pembungaan dan meningkatkan masa bunga. Berdasarkan hal tersebut maka semakin tersedia air dan nutrisi yang stabil pada fase vegetatif dan geratif, maka semakin tinggi pertumbuhan dan hasil tanaman tersebut. Kebutuhan hara berdasar suplai dari luar, larutan nutrisi yang diberikan terdiri atas garam - garam makro dan mikro yang dibuat dalam larutan A dan B. Larutan A terdiri dari unsur N, K, Ca dan Fe. Sedangkan larutan B terdiri atas unsur $\mathrm{P}, \mathrm{Mg}, \mathrm{S}, \mathrm{B}, \mathrm{Mn}$, $\mathrm{Cu}, \mathrm{Na}$, Mo dan $\mathrm{Zn}$. Selain itu, nutrisi yang terdiri dari unsur hara makro dan mikro merupakan hara yang mutlak diperlukan untuk memperbaiki pertumbuhan tanaman (Karsono et al., 2002).

Tabel 3. Pengaruh Pupuk NPK Majemuk, Pupuk Daun dan POC Urin Sapi pada Hidroponik Sistem Wick terhadap Rata-rata Tinggi Bunga, Diameter Bunga, Bobot Bunga Tanpa Daun, dan Bobot Bunga dengan Daun.

\begin{tabular}{|c|c|c|c|c|c|c|c|c|c|}
\hline \multirow[b]{2}{*}{$\begin{array}{l}0 \\
0 \\
\forall\end{array}$} & \multirow[b]{2}{*}{ Perlakuan } & \multicolumn{8}{|c|}{ Komponen Hasil Bunga per Tanaman } \\
\hline & & \multicolumn{2}{|c|}{$\begin{array}{l}\text { Tinggi } \\
(\mathrm{cm})\end{array}$} & \multicolumn{2}{|c|}{$\begin{array}{l}\text { Diameter } \\
(\mathrm{cm})\end{array}$} & \multicolumn{2}{|c|}{$\begin{array}{c}\text { Bobot tanpa } \\
\text { daun (gr) }\end{array}$} & \multicolumn{2}{|c|}{$\begin{array}{c}\text { Bobot dengan } \\
\text { Daun (gr) }\end{array}$} \\
\hline A & AB Mix $10 \mathrm{ml} \mathrm{L}^{-1}$ air & 8,18 & a & 12,70 & $\mathrm{a}$ & 207,57 & a & 536,056 & a \\
\hline B & Urine sapi $100 \mathrm{ml} \mathrm{L}^{-1}$ air & 3,53 & $\mathrm{e}$ & 8,65 & $\mathrm{c}$ & 143,79 & $\mathrm{~d}$ & 359,556 & $b$ \\
\hline $\mathrm{C}$ & Gandasil $4 \mathrm{gr} \mathrm{L}^{-1}$ air & 2,35 & $\mathrm{f}$ & 6,08 & $\mathrm{~d}$ & 127,83 & $\mathrm{e}$ & 252,056 & $\mathrm{c}$ \\
\hline $\mathrm{D}$ & NPK 21,6 gr/tanaman & 4,60 & $\mathrm{~d}$ & 9,18 & bc & 141,70 & de & 302,889 & $\mathrm{bc}$ \\
\hline $\mathrm{E}$ & NPK 21,6 gr/ tanaman + Gandasil $2 \mathrm{gr} \mathrm{L}^{-1}$ air & 4,47 & $\mathrm{~d}$ & 8,47 & $\mathrm{c}$ & 135,59 & de & 367,667 & $\mathrm{~b}$ \\
\hline $\mathrm{F}$ & NPK 21,6 gr/ tanaman +Gandasil $4 \mathrm{gr} \mathrm{L}^{-1}$ air & 6,10 & bc & 9,10 & $\mathrm{bc}$ & 157,20 & $\mathrm{c}$ & 365,389 & $\mathrm{~b}$ \\
\hline G & NPK 21,6 gr/ tanaman + Gandasil $6 \mathrm{gr} \mathrm{L}^{-1}$ air & 6,58 & $\mathrm{~b}$ & 9,35 & bc & 162,99 & $\mathrm{c}$ & 389,111 & $\mathrm{~b}$ \\
\hline $\mathrm{H}$ & NPK 21,6 gr/ tanaman + Urine Sapi $80 \mathrm{ml} \mathrm{L}^{-1}$ air & 6,57 & $\mathrm{~b}$ & 9,33 & $\mathrm{bc}$ & 144,16 & $\mathrm{~d}$ & 388,889 & $\mathrm{~b}$ \\
\hline I & NPK 21,6 gr/ tanaman + Urine Sapi $100 \mathrm{ml} \mathrm{L}^{-1}$ air & 6,74 & $\mathrm{~b}$ & 9,94 & $\mathrm{~b}$ & 176,32 & $\mathrm{~b}$ & 394,167 & $\mathrm{~b}$ \\
\hline $\mathrm{J}$ & NPK 21,6 gr/ tanaman + Urine Sapi $120 \mathrm{ml} \mathrm{L}^{-1}$ air & 5,55 & $\mathrm{c}$ & 9,21 & $\mathrm{bc}$ & 141,86 & $\mathrm{~d}$ & 379,944 & $\mathrm{~b}$ \\
\hline & KK (Koefisien Keragaman) \% & \multicolumn{2}{|c|}{8,38} & \multicolumn{2}{|c|}{6,65} & 3,89 & & \multicolumn{2}{|c|}{14,31} \\
\hline
\end{tabular}

Keterangan: Nilai rata-rata pada kolom yang sama yang diikuti huruf yang sama menunjukan tidak berbeda nyata pada uji lanjut DMRT taraf 5\% 
- NPK 21,6 gr/ tanaman + Urine Sapi $120 \ldots$

- $\quad$ NPK 21,6 gr/ tanaman + Urine Sapi 100...

I $\quad$ NPK $21,6 \mathrm{gr} /$ tanaman + Urine Sapi $80 \ldots$

( $\quad$ NPK $21,6 \mathrm{gr} /$ tanaman + Gandasil $6 \ldots$

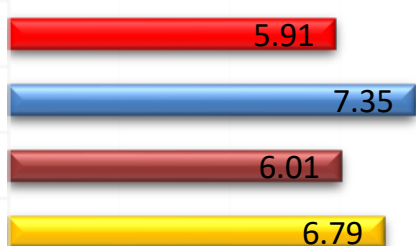

ᄂ $\quad$ NPK 21,6 gr/ tanaman +Gandasil 4 gr/lt...

$w \quad$ NPK $21,6 \mathrm{gr} /$ tanaman + Gandasil $2 \ldots$

○ NPK $21,6 \mathrm{gr} /$ tanaman

৩ Gandasil $4 \mathrm{gr} / \mathrm{lt}$ air

の $\quad$ Urine sapi $100 \mathrm{ml} / \mathrm{lt}$ air

$\varangle \quad$ AB Mix $10 \mathrm{ml} / \mathrm{lt}$ air
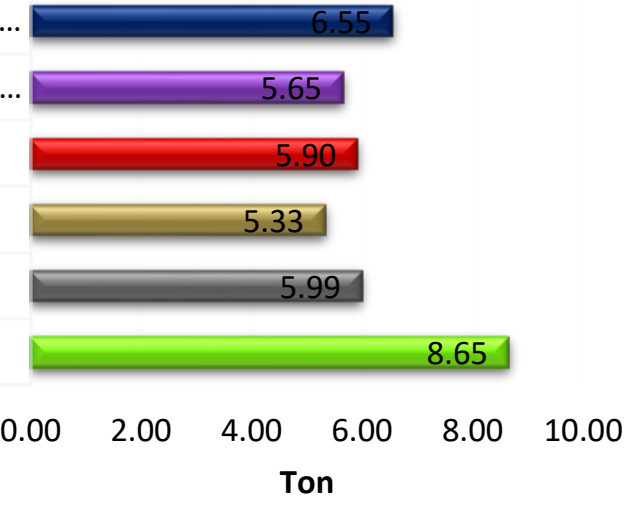

Gambar 1. Diagram Pengaruh Pupuk NPK Majemuk, Pupuk Daun dan POC Urin Sapi pada Hidroponik Sistem Wick terhadap Bobot Bunga Tanpa Daun perhektar

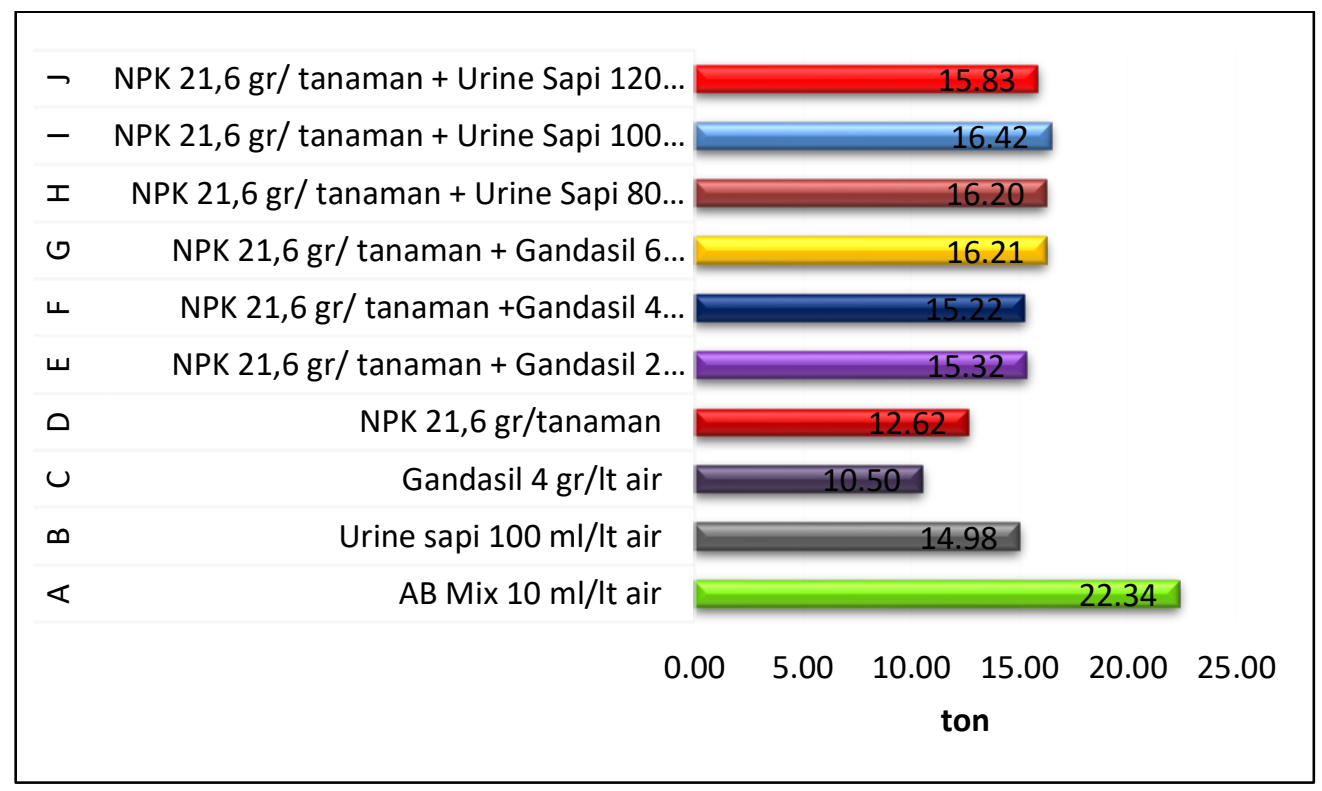

Gambar 2. Diagram Pengaruh Pupuk NPK Majemuk, Pupuk Daun dan POC Urin Sapi pada Hidroponik Sistem Wick terhadap Bobot Bunga Dengan Daun perhektar 
Berdasarkan hasil konversi ke hektar, perlakuan $\mathrm{A}$ ( $\mathrm{AB} \quad \mathrm{Mix} \quad 10 \mathrm{ml} \quad \mathrm{L}^{-1} \quad$ air) memberikan bobot bunga tanpa daun tertinggi sebesar 8,65 ton/ha berbeda nyata dengan perlakuan lainya, namun masih jauh dari deskripsi kultivar PM126F1 (Gambar 1). Hal ini diduga saat fase generatif peningkatan suhu lingkungan sangat tinggi mencapai rata-rata $34,35^{\circ} \mathrm{C}$, sehingga terganggu metabolisme tanaman saat pengisian masa bunga. Suhu yang terlalu tinggi mempercepat penutupan stomata, sehingga menghambat masuknya $\mathrm{CO}_{2}$ sebagai bahan fotosintesis masuk ke daun. Selain itu suhu lingkungan yang semakin tinggi menyebabkan laju respirasi lebih tinggi dibandingkan laju fotosintesis, yang membuat terjadinya penyusutan jumlah fotosisntat yang berakibat kurang maksimalnya proses pengisian masa bunga, walau kebutuhan unsur hara makro dan mikro esensial terpenuhi. Menurut Pracaya (2011) kubis bunga dataran rendah memerlukan suhu $28{ }^{\circ} \mathrm{C}-32{ }^{\circ} \mathrm{C}$ selama siklus hidupnya. Apabila tidak terpenuhi maka akan terganggu pertumbuhan vegetatif dan waktu pembungaannya.

Berdasarkan hasil konversi ke hektar, perlakuan A (AB Mix $10 \quad \mathrm{ml}^{-1} \quad \mathrm{~L}^{-1}$ air) memberikan bobot bunga dengan daun tertinggi sebesar 22,34 ton/ha berbeda nyata dengan perlakuan lainya (Gambar 2). Hal ini diduga peningkatan suhu hanya terjadi saat fase generatif, sedangkan saat fase vegetatif suhu lingkungan optimal sehingga komponen pertumbuhan (batang, daun, akar, dan luas daun) memberikan respon yang optimal yang berkorelati terhadap penambahan bobot basah tanaman. Pada kondisi suhu optimal laju trnaslokasi fotosintat dari daun ke jaringan meristem berjalan maksimal sehingga proses repirasi bisa optimal. Berdasarkan hal tersebut maka semakin optimal kondisi suhu lingkungan saat fase vegetatif maka semakin tinggi biomasa basah tanaman. Menurut Dwijosaputro (1991) unsur hara dalam keadaan cukup maka biosintesis dapat berjalan dengan lancar, sehingga karbohidrat yang dihasilkan akan semakin banyak dan dapat disimpan sebagai cadangan makanan dan pada akhirnya terjadi peningkatan berat basah tanaman.

\section{KESIMPULAN}

Optimasi pupuk NPK majemuk, pupuk daun dan POC urin sapi pada hidroponik sistem wick memberikan pengaruh yang berbeda nyata terhadap komponen pertumbuhan (tinggi tanaman 42 hst, jumlah daun 42 hst, diameter batang 42 hst, pajang akar, dan luas daun), serta memberikan pengaruh yang berbeda nyata terhadap komponen hasil (tinggi bunga, diameter bunga, bobot bunga tanpa daun, dan bobot bunga dengan daun) tanaman kubis bunga kultivar PM126F1. Perlakuan A (AB Mix 10 $\mathrm{ml} \mathrm{L}^{-1}$ air) memberikan hasil tertinggi pada bobot bunga (krop) dengan daun per tanaman sebesar 536,056 gr setara dengan 22,34 ton per hektar dan bobot bunga (krop) tanpa daun per tanaman sebesar 207,57 gr setara dengan 8,65 ton per hektar

Untuk mengatasi alih fungsi lahan dan peningkatan produktivitas pertanian perkotaan, perlu adanya penerapan pertanian non konvensional salah satunya hidroponik. Hasil penelitian ini merekomendasikan penerapan hidroponik wick sistem dengan nutrisi $\mathrm{AB}$ Mix $10 \mathrm{ml} \mathrm{L}^{-1}$ air akan mampu memberikan hasil bobot bunga (krop) dengan daun per tanaman sebesar 536,056 gr setara dengan 22,34 ton per hektar dan bobot bunga (krop) tanpa daun per tanaman sebesar 207,57 gr setara dengan 8,65 ton per hektar. 


\section{DAFTAR PUSTAKA}

Dharmayanti, N.K.S., A.A.N. Supadma, and I.D.M. Arthagama. 2013. Pengaruh Pemberian Biourine dan Dosis Pupuk Anorganik (N,P,K) Terhadap Beberapa Sifat Kimia Tanah Pegok dan Hasil Tanaman Bayam (Amaranthus sp.). EJurnal Agroekoteknologi Trop. 2(3): $165-174$.

Dwijosaputro. 1991. Pengantar Fisiologi Tanaman. PT. Gramedia, Jakarta.

Erawan, D., W.O. Yani, and A. Bahrun. 2013. Pertumbuhan Dan Hasil Tanaman Sawi (Brassica juncea L.) Pada Berbagai Dosis Pupuk Urea. J. Agroteknos 3(1): 19-25.

Gardner, F., P. RB, and M. RL. 1991. Physiology of Crop Plants (Fisiologi Tanaman Budidaya). Jakarta: Universitas Indonesia Press. Universitas Indonesia Press, Jakarta.

Halim, J. 2016. 6 Teknik Hidroponik. Penebar Swadaya Grup, Jakarta.

Hartatik, W., Husnain, and L.R. Widowati. 2015. Peranan Pupuk Organik dalam Peningkatan Produktivitas Tanah dan Tanaman. J. Sumberd. Lahan 9(2): 107120.

http://www.ejurnal.litbang.pertanian.go.i d/index.php/jsl/article/download/6600/58 59.

Karsono, S., Sudarmodjo, and Y. Sutiyoso. 2002. Hidroponik: Skala Rumah Tangga. PT AgroMedia Pustaka. Jakarta. 64 hal. PT. Agromedia Pustaka, Jakarta.

Kusumah, M., M. Mulyono, and S.S. Dewi. 2016. Pengaruh Berbagai Macam Sumber Nutrisi Terhadap Pertumbuhan Dan Hasil Tanaman Tomat (Licopersicum esculentum Mill) Pada Ssistem Hidroponik Sumbu. http://repository.umy.ac.id/handle/12345 6789/6480?show=full.

Lingga, P., and Marsono. 2007. Petunjuk Penggunaan Pupuk. Penebar Swadaya, Jakarta.

Munawar, A. 2011. Kesuburan Tanah dan Pupuk Tanaman. Bogor. IPB Press. IPB
Press, Bogor.

Perwowidodo. 1992. Telaah Kesuburan Tanah. Angkasa, Bandung.

Pracaya. 2011. Kol alias Kubis. Penebar Swadaya, Jakarta.

Roidah, I.S. 2014. Pemanfaatan Lahan Dengan Menggunakan Sistem Hidroponik. J.

Univ. Tulungagung Bonorowo 1(43-50). http://www.jurnalunita.org/index.php/bonorowo/article/vie $\mathrm{w} / 14$. 